Janusz Miąso*

Rzeszów

\title{
Komunikacja interpersonalna a proces przebaczania
}

Na początku należy stwierdzić, że Chrystus stworzył nie tylko system religijny, ale także system społeczny, w którym koncepcja człowieka jako istoty religijnej, żyjącej życiem wiecznym, jest zapewne najważniejsza. Nie mniej ważne są kwestie dotyczące samego człowieka jako osoby ${ }^{1}$, a więc kogoś autonomicznego, samoistnego, z natury dobrego, żyjącego światem wartości a zarazem zdolnego wznosić się na szczyty ludzkich możliwości dzięki prawdzie, dobru, pięknu i miłości, jak również kwestie społeczne, które bardzo dobrze wybrzmiewają w chrześcijaństwie i stały się siłą wielkich europejskich i światowych kultur. Wśród nich prawda o całkowitej ontycznej równości mężczyzny i kobiety, o roli małżeństwa, jako trwałego związku mężczyzny i kobiety, o bezcennej wartości dzieciństwa, o równości wszystkich ludzi, o miłości i solidarności społecznej jako drogach prowadzących do lepszego społeczeństwa.

Punktem wyjścia chrześcijańskiej koncepcji człowieka jest prawda o człowieku stworzonym na obraz i podobieństwo Boga, a Bóg w chrześcijaństwie jest Bogiem miłości i przebaczenia. Prawdę tę ukazuje cały Stary Testament i kontynuuje Nowy Testament, najdoskonalej w Osobie Twórcy

* Ks. dr hab. Janusz Miąso, prof. UR, jest profesorem w Katedrze Pedagogiki Medialnej w Wydziale Pedagogicznym Uniwersytetu Rzeszowskiego. Adres: Wydział Pedagogiczny Uniwersytetu Rzeszowskiego, Aleja Rejtana 16c, 35-959 Rzeszów; e-mail: jmiaso@univ.rzeszow.pl.

1 Zob. Czesław S. Bartnik, Personalizm (Lublin: KUL, 2000). 
chrześcijaństwa - w Osobie Jezusa Chrystusa, który zapytany o to, ile razy należy wybaczyć, odpowiada, że aż siedemdziesiąt siedem razy, czyli w nieskończoność, i który nawet na krzyżu, w sytuacji skrajnie ekstremalnej, wybacza swoim oprawcom, ukazując i promując w ten sposób zdolność człowieka do przebaczenia.

Ta bardzo pozytywna koncepcja człowieka i społeczeństwa staje się jeszcze bardziej wyraźna w kontekście aktualnych ,spotkań” z innymi kulturami, gdzie coraz mocniej widać, iż równość mężczyzny i kobiety nie jest taka oczywista, a szacunek dla człowieczeństwa nie jest wartością wysoko cenioną ${ }^{2}$.

Przebaczenie i dojrzewanie do przebaczenia, które stanowi istotny wymiar dojrzewania chrześcijańskiego, jest przedmiotem badań w ramach niniejszego tekstu. Refleksja nad nim zostanie przeprowadzona w perspektywie wyników współczesnych badań nad komunikacją interpersonalną. Tekst będzie zatem próbą odpowiedzi na pytanie, jak komunikacja interpersonalna warunkuje proces przebaczania i jak wychowywać do umiejętności przebaczania poprzez pracę nad jakością komunikacji interpersonalnej. Rozważania rozpoczęte zostaną od refleksji nad komunikacją interpersonalną, by następnie określić, jak trudności w zakresie samej komunikacji, jej odniesieniach do prawdy i atmosfery miłości przekładają się na braki w przebaczeniu.

\section{Komunikacja interpersonalna w prawdzie ku milości}

Przyjrzyjmy się najpierw cechom dobrej komunikacji interpersonalnej, warunkującej budowanie relacji międzyludzkich, a tym samym i procesów przebaczania.

Komunikacja interpersonalna jest procesem wymiany, wymiany dwukierunkowej, wymiany systemu wartości obu stron komunikacji. Drogą do doskonalenia komunikacji jest komunikacja w prawdzie i miłości, a więc odsłaniająca prawdę o komunikujących, ale w klimacie wzajemnej życzliwości i miłości, gdzie może pojawiać się właśnie kategoria przebaczenia, gdy prawda albo miłość bywają okłamane. Także dla intensyfikacji wymiany komunikacyjnej istotne będzie wspólne podążanie w kierunku prawdy, piękna i dobra, które to kategorie przeżywają swoje trudności w komunika-

2 Zob. Jan Szmyd, Zagrożone człowieczeństwo. Regresja antropologiczna w świecie ponowoczesnym (Katowice: Śląsk Wydawnictwo Naukowe, 2015). 
cji zapośredniczonej medialnie, gdzie prawda o stronach komunikacji bywa często zafałszowana, piękno preparowane a dobro różnie rozumiane, często bez kontekstu etycznego. W takich sytuacjach dużo trudniej o przebaczenie. Generalnie w procesie komunikacji zapośredniczonej medialnie będzie dużo trudniej o proces wymiany wartości w klimacie prawdy i miłości.

$\mathrm{Na}$ komunikację interpersonalną składają się znaki i symbole. Znaki pomagają nam zorientować się, w jakim kierunku podążać lub nie. Umiejętność czytania znaków płynących od drugiego człowieka to zdolność zrozumienia jego różnych stanów osobowościowych. Empatia pomaga czytać znaki. Może to być znak, że w tej chwili jest trudno o przebaczenie, ale potrzeba czasu i wszystko może będzie możliwe. Natomiast symbole odnoszą nas do jakiejś innej rzeczywistości, do kogoś innego. Bogata symbolika w chrześcijaństwie nieustannie przypomina nam o Bogu, miłości, przebaczeniu, które płynie w nurcie bożego miłosierdzia od Boga do człowieka, dlatego też winna biec także od człowieka do człowieka (,,podobnie uczyni wam Ojciec mój niebieski, jeżeli każdy z was nie przebaczy z serca swemu bratu...": Mt 18, 21-35).

Komunikacja interpersonalna tworzy znaczenia. Aby znaki i symbole były w ogóle ważne, muszą mieć jakieś znaczenie. Znaczenie jest podstawą komunikacji, bez niego komunikacja nie istnieje, natomiast to właśnie komunikacja interpersonalna odgrywa aktywną rolę w nadawania sensu komunikatom na podstawie kultury, w której żyją osoby w nią zaangażowane, poczucia czasu, relacji między osobami, celów oraz sytuacji, w której komunikat jest odbierany.

Komunikacja interpersonalna przebiega w interakcji, stanowiącej ogromną szansę dla każdego z uczestników, którzy mogą się zaangażować w proces komunikacji, mogą zarazem odbierać i wysyłać komunikaty, mogą przebaczać i prosić o przebaczenie, mogą argumentować i słuchać argumentacji - to wszystko jest istotne dla procesu wzajemnego zrozumienia i przebaczenia. Bez wnikliwej diagnozy obydwu stron komunikacji opartej na interaktywnej wymianie stanowisk, w której dokonuje się wspólne poszukiwanie prawdy, bardzo trudno o wybaczenie i wspólne podążanie w stronę lepszych relacji oraz o budowanie związku interpersonalnego na wyższym poziomie wzajemnej życzliwości i miłości.

Komunikacja interpersonalna jest relacyjna. Budowanie i wzmacnianie relacji płynie $\mathrm{z}$ interaktywności, ale także $\mathrm{z}$ bogactwa treści, którymi osoby wzajemnie się ubogacają. Związek bez treści, także treści o możliwości wzajemnego wybaczenia, może zdążać w kierunku osłabienia, a nawet zaniku, dlatego też tak ważna jest dynamika relacji, jak też bogactwo treści w ko- 
munikacji interpersonalnej, które to ożywiają i wzmacniają związki międzyludzkie.

Komunikacja interpersonalna przyczynia się do powstawania związków międzyludzkich. Konsekwencją interaktywności i relacyjności komunikacji interpersonalnej jest powstawanie, a także ciągłe ożywianie związków międzyludzkich na wszystkich poziomach życia. Związek oznacza dłuższy czas trwania interakcji, jak również powstanie współzależności - strony pragną bowiem osiągać wówczas wspólne cele przez wspólne pielęgnowanie komunikacji dla wyższej wartości, jaką może być rozwój indywidualny i społeczny. Ów rozwój dokonuje się głównie we wspólnotach, gdzie bez wspólnej dobrej komunikacji trudno osiągać wyższe cele; przede wszystkim w rodzinie, gdzie przez permanentną wybaczającą komunikację budowane są związki, przyczyniające się do rozwoju indywidualnego i społecznego.

Komunikacja interpersonalna przebiega etapami. Etapy tworzenia związku dosyć powszechnie bywają określane według następujących faz: poznawanie się, rozwój relacji, osłabienie relacji, w wyniku którego może nastąpić rozpad związku lub jego ożywienie i trwanie. Etapy związków międzyludzkich - określane jako wzloty i upadki, radości i smutki, konflikty, urazy i wybaczenia - mają swoją fluktuację, zapewne inną dla każdego związku. Zdolność przebaczenia bywa na pewno jedną z najważniejszych zdolności, istotną dla ciągłego ożywiania związku - każdy bowiem ma swoje wady i zalety. W miarę trwania związku druga strona coraz lepiej je zna i doświadcza ich konsekwencji, dlatego też utrzymanie związku wymaga coraz większej zdolności przebaczania. Edukacja ku zdolności wybaczania dokonuje się poprzez proces komunikacji, w którym człowiek staje wobec konieczności przyjęcia całej prawdy o sobie i o drugiej osobie, aby oczyścić relację oraz wzmocnić ją. Bez edukacji w zakresie zdolności przebaczenia trudno o pokonywanie trudności w relacjach międzyludzkich ${ }^{3}$.

\section{Problemy z komunikacją a trudności z przebaczeniem}

Problemy z komunikacją są jednymi z podstawowych trudności w nawiązywaniu relacji, podtrzymywaniu relacji, a także odbudowywaniu relacji w sytuacjach kryzysowych, gdy trzeba wybaczyć i na nowo coś zbudować.

3 Sherwyn P. Morreale, Brian H. Spitzberg, J. Kevin Barge, Komunikacja między ludźmi, tłum. Dorota Kobylińska, Paweł Izdebski, Aleksandra Jaworska-Surma (Warszawa: Wydawnictwo Naukowe PWN, 2008), 280-287. 
Marek Dziewiecki podpowiada następującą zwięzłą typologię barier w komunikacji, których znajomość może być bardzo pomocna w procesie przebaczenia, oczyszczania i odbudowywania relacji interpersonalnych.

Pierwsza kwestia, na którą zwraca uwagę, to kwestia subiektywnego spostrzegania rzeczywistości, który to subiektywizm dziś jeszcze bardziej się pogłębia, bo coraz większa część ludzi pragnie mieć swój świat, swoją wizję życia (zjawisko singlizmu i wiele innych), całkowicie niezależną od drugiego człowieka. Fakt, że każdy człowiek patrzy na siebie i otaczający go świat w sposób subiektywny, a także, że otaczający świat interpretujemy i przeżywamy w sposób odmienny, może być i bywa pewną trudnością komunikacyjną, ale może być także bogactwem spojrzeń. Subiektywność spojrzeń staje się odczuwalna w sposób wyjątkowo silny w sytuacjach konfliktu. Wtedy każdemu z komunikujących grozi takie interpretowanie danej sytuacji lub wydarzenia, by było dla niego korzystne, nawet jeśli w oczywisty sposób nie jest to zgodne z prawdą. Trudności te związane są z różnicami w osobowości i w wychowaniu, z indywidualną historią życia, z odmiennymi doświadczeniami, potrzebami, zainteresowaniami, ideałami, wizjami siebie i świata. Gdy we wzajemnych kontaktach nie uwzględnia się odmienności indywidualnych spojrzeń na poszczególne osoby oraz na świat, który je otacza, to porozumienie się okazuje się trudne, a czasem niemożliwe. By skutecznie przezwyciężać te bariery, trzeba mieć zdolność (i ciągle jej się uczyć) odróżniania obiektywnej rzeczywistości i obiektywnej prawdy dotyczącej faktów od własnych przekonań czy interpretacji. Warto także przyznawać drugiej stronie prawo do odmiennego spojrzenia na te same wydarzenia czy sytuacje. Można się nie zgadzać z punktem widzenia drugiego człowieka, ale by budować mosty, należy przyznać rozmówcy prawo do odmienności spojrzenia. Trzeba ponadto wymagać od siebie, by spróbować zrozumieć to jego subiektywne spojrzenie, zanim zaczniemy je oceniać. Warto pamiętać, że gdyby drugi człowiek był taki sam jak my oraz gdyby wszystko widział w podobny sposób, to nie byłby nam potrzebny. Możemy rosnąć i rozszerzać nasze horyzonty przeżyć i doświadczeń tylko poprzez spotkania z ludźmi, którzy są odmienni od nas. Pod warunkiem, że są to prawdziwe spotkania, w których obie strony starają się zrozumieć siebie nawzajem, mimo odmiennych sposobów rozumienia i przeżywania danej rzeczywistości ${ }^{4}$.

Druga trudność komunikacyjna dotyczy błędnych form wypowiedzi wyrażania prawdy. Otóż komunikacja między ludźmi służy nie tylko przekazywaniu określonych treści czy informacji, lecz jednocześnie jest sposobem

${ }^{4}$ Marek Dziewiecki, Psychologia porozumiewania się (Kielce: Jedność 2000), 10-12. 
określania wzajemnej postawy komunikujących się wobec siebie. Bariery w komunikacji międzyludzkiej pojawiają się wtedy, gdy ktoś próbuje komunikować się z innym w taki sposób, by narzucić określony rodzaj relacji czy więzi, których ten drugi sobie nie życzy lub których nie akceptuje. Określanie postawy wobec drugiego człowieka dokonuje się czasem poprzez treść rozmowa o życzliwości prowadzona w tonie przebaczającym może wyrażać właśnie postawę zrozumienia, przebaczenia. Często określanie postawy wobec drugiej osoby czynimy poprzez formę, w jakiej się do niej zwracamy forma raniąca, ciągle coś wyrzucająca i ciągle przypominająca jakieś słabości może być formą zwiększającą bariery w komunikacji ku przebaczeniu5 .

Kolejna trudność komunikacyjna, dosyć często dziś występująca, to zaburzona koncentracja uwagi, na którą bardzo dobrze zwraca uwagę Daniel Goleman w książce Focus ${ }^{6}$. Prawidłowa komunikacja wymaga, by każdy z komunikujących w sposób proporcjonalny skupiał uwagę na drugiej osobie, na samym sobie, a także na przekazywanej i odbieranej treści. Trudności z prawidłową komunikacją pojawiają się wtedy, gdy ktoś z komunikujących nadmiernie się skupia na jednym z powyższych elementów komunikacji. Sygnalizowana trudność może przybierać trzy główne postaci. Po pierwsze może oznaczać nadmierną koncentrację na samym sobie - dzieje się tak zwykle wtedy, gdy dana osoba czuje się zbytnio i jednostronnie odpowiedzialna za przebieg komunikacji, albo gdy nie jest pewna siebie i czuje się zmuszona do kontrolowania każdego swego gestu czy słowa, albo gdy z jakiegoś powodu pragnie zrobić na drugiej osobie dobre wrażenie, a także gdy ten przekaz ma dla niej szczególne znaczenie. Nadmierna koncentracja komunikującego na sobie samym jest bardzo kłopotliwa, może powodować rosnącą nerwowość, niepewność, napięcie emocjonalne, niepokój o to, co o mnie myśli i jak mnie ocenia druga osoba. Przesadna koncentracja na sobie może być źródłem silnej frustracji i ostatecznie może wyrażać brak zaufania do samego siebie lub do partnera komunikacji, a ostatecznie może być trudnością we wzajemnym przebaczeniu, ponieważ trudno wówczas skoncentrować się na treści komunikatu, który może być esencją problemu. Drugą formą niewłaściwej koncentracji uwagi jest nadmierna koncentracja na drugiej osobie, może ona przejawiać się na przykład w dążeniu do odgadnięcia myśli partnera, w usiłowaniu „przejrzenia” jego wnętrza i jego zamiarów. Ostatecznie owa nadmierna koncentracja wyraża podejrzliwość i nieufność

5 Tamże, 13-16.

${ }^{6}$ Zob. Daniel Goleman, Focus. Sztuka koncentracji jako ukryte dążenie do doskonałości (Poznań: Media Rodzina, 2014). 
wobec drugiej osoby, może się wiązać z przypisywaniem mu nieuczciwych, złych zamiarów, manipulacji. W takiej sytuacji nie jest możliwa szczera, pogłębiona, przebaczająca, wyrozumiała komunikacja. Trzecią formą omawianej trudności jest nadmierna koncentracja na treści i na samym przebiegu rozmowy. Wtedy komunikującemu coraz trudniej o respektowanie drugiej strony, a nawet samego siebie i może to prowadzić do coraz większego niepokoju, zmęczenia, a ostatecznie uniemożliwienia autentycznego spotkania. Pomocą w pokonywaniu tych trudności może być atmosfera życzliwości i ufności - czasem wystarczy, by na początku komunikacji pojawił się serdeczny uśmiech, życzliwe słowo, gest przyjaźni. Pomocną może być także delikatność i subtelność w budowaniu relacji, wzmacniające poczucie bezpieczeństwa, co może prowadzić do atmosfery komunikacyjnej ułatwiającej przebaczanie ${ }^{7}$.

Kolejna trudność komunikacyjna, stanowiąca także problem w przebaczeniu, to negatywne oczekiwania wobec rozmówcy. Gdy spotykamy się z drugą osoba albo choćby tylko myślimy o perspektywie spotkania i rozmowy z nią, to w sposób spontaniczny pojawiają się w naszej świadomości określone przekonania i oczekiwania. Zakładamy czy spodziewamy się, że z danym człowiekiem rozmowa będzie miła i szczera, a z kimś innym raczej nieprzyjemna bądź agresywna. Czasami nasze przekonania wypływają z poprzednich doświadczeń i są dosyć logiczne, często jednak są bezpodstawne i bywają bardziej związane $\mathrm{z}$ naszą ogólną wizją siebie i świata niż z faktyczną znajomością cech, podstaw danego rozmówcy. Nasze oczekiwania i przewidywania wobec drugiej strony komunikacji mogą więc raczej zależeć od naszych nastawień czy stanów wewnętrznych niż od rzeczywistych cech lub zachowań osób współkomunikujących. Oczekiwania negatywne, tak zwane uprzedzenia, stają się zwykle przyczyną poważnych trudności komunikacyjnych. Dzieje się tak dlatego, że tego typu oczekiwania czasem się spełniają, są rodzajem samospełniającej się przepowiedni, także wtedy, gdy są one zupełnie błędne czy bezpodstawne. Są one często trudnością blokującą przebaczenie, gdy już z góry zakładamy pewien stan rzeczy, nie dając możliwości wyjaśnienia całości problemu. Powinniśmy więc być ostrożni i krytyczni wobec naszych oczekiwań i ,przepowiedni”. Jeśli ktoś się spodziewa, że druga strona będzie wobec niego agresywna i nieżyczliwa, to prawdopodobnie tak się stanie, nawet wtedy, gdyby partner był do nas nastawiony bardzo życzliwie. Drogą do właściwej przebaczającej komunikacji jest droga pokory i odwagi, związana z przemianą czegoś istotnego we wła-

\footnotetext{
${ }^{7}$ Dziewiecki, Psychologia, 16-18.
} 
snym wnętrzu czy w naszej postawie wobec innych - chodzi o pozytywne i życzliwe spojrzenie na siebie i innych motywujące do zrozumienia i przebaczenia, do pozytywnej wizji świata i drugiego człowieka ${ }^{8}$.

Kolejną trudnością komunikacyjną $\mathrm{w}$ procesie przebaczenia jest tak zwana komunikacja równoległa, polegająca na tym, że każdy z komunikujących próbuje za wszelką cenę przeforsować własną myśl czy też własną wizję, nie reagując na to, co mówi i co przeżywa druga osoba. Ten drugi z kolei czyni podobnie, próbując przekonać pierwszego do własnych racji, nie reagując na jego argumenty. Wówczas właśnie mamy do czynienia $z$ tak zwaną komunikacją równoległą, ale przeciwko sobie. Jest to sytuacja, w której obaj partnerzy komunikują według własnego, z góry ułożonego planu, własnej wizji, nie zwracając uwagi na to, co mówi druga osoba. Tego typu komunikacja może trwać długo i doprowadzić w końcu do ostrego konfliktu, gdy któraś ze stron zorientuje się, że współrozmówca w ogóle go nie słucha. Pojawia się wtedy tak zwana spirala negatywna, co oznacza, że każda kolejna wymiana słów prowadzi do coraz większego napięcia i agresywności z obydwu stron. Konstatacja jest następująca - dopóki trwa komunikacja równoległa, żadne porozumienie nie jest możliwe. Musi nastąpić moment zatrzymania i refleksji, iż ta komunikacja prowadzi do destrukcji relacji i jest tylko narzucaniem własnych wizji bez poszukiwania konsensusu. Gdy po zatrzymaniu dojdziemy do momentu, w którym obydwie strony komunikacji podejmą decyzję o konieczności zmiany tej sytuacji i zaczną się nawzajem słuchać, jest to szansa na powrót do przebaczającego dialogu9.

Trudność w komunikacji i przebaczeniu może dotyczyć także subiektywnego przypisywania odpowiedzialności, które wynika z jednej z ważnych cech ludzkiego myślenia, jaką jest poszukiwanie przyczynowości. Fakt ujmowania wszystkich wydarzeń w kategoriach przyczyny i skutku może stać się źródłem istotnych zaburzeń w procesie komunikacji międzyludzkiej, a konsekwentnie także przebaczenia. Dana osoba może bowiem zupełnie inaczej interpretować określone zjawisko niż druga osoba w komunikacji. Gdy sprawa zaczyna nas bezpośrednio dotyczyć, to tego typu różnice mogą diametralnie zwiększać napięcie w komunikacji i osłabiać możliwość porozumienia. Drogą do porozumienia jest próba spojrzenia na daną problematykę oczyma drugiej strony, a także uwzględnienie możliwie jak najszerszego kontekstu zdarzeń i całej historii problemu ${ }^{10}$.

\footnotetext{
8 Tamże, 18-20.

9 Tamże, 20-22.

10 Tamże, 22-25.
} 
Jeszcze jedna istotna trudność w komunikacji została nazwana przez Marka Dziewieckiego komunikacją paradoksalną. Wprowadza ona szczególny szum informacyjny i osłabia możliwość porozumienia się i przebaczenia, a związana jest $\mathrm{z}$ wewnętrzną sprzecznością w informacjach, które dana osoba przekazuje drugiej werbalnie i niewerbalnie. Komunikacja paradoksalna prowadzi do paradoksów i załamań komunikacyjnych i decyzyjnych oraz wymaga naprawdę wielkiego wysiłku w przełamaniu tych trudności ku wejściu na drogę przebaczenia i porozumienia ${ }^{11}$.

Marek Dziewiecki podsumowując trudności w komunikacji, które starałem się zaadaptować na potrzeby komunikacji przebaczającej, podkreśla, iż przedstawione bariery w komunikacji międzyludzkiej należą do najważniejszych, ale nie są jedynymi trudnościami. Jest ich tak wiele, jak wiele jest ludzkich sposobów komunikowania się i wzajemnego odnoszenia do siebie. Stajemy zatem wobec pytania, jak je przezwyciężać? Bardzo istotną sprawą jest ciągła obserwacja siebie i innych, doskonalenie siebie i procesu komunikacji, głównie jednak w klimacie miłości do drugiego człowieka i w perspektywie prawdy, która wyzwala, a miłość daje siłę do komunikacji przebaczającej, wznoszącej na wyższe poziomy wspólnego lepszego życia ${ }^{12}$.

\section{Kryzys prawdy jako podłoże trudności w komunikacji i w przebaczeniu}

W książce Nasycone Ja amerykański psycholog Kenneth Gergen jeden z fragmentów nazwał znamiennie: ,prawda w kłopotach”. Stwierdza w nim:

obserwujemy zatem systematycznie rosnącą podejrzliwość wobec obiektywnych prawd nauki lub wszystkich innych grup głoszących prawdę swego języka; nieuprawnione jest domaganie się uznania prymatu danego stanowiska na podstawie faktualnej dokładności, gdyż objaśnienia „sposobu w jaki funkcjonuje świat", nie wyrastają z natury, lecz z zastosowania społecznie podzielanej perspektywy; czym zatem jest „fakt” w ramach takiego objaśnienia?

Profesor Gergen przywołuje Mary Hawksworth, która ujmuje to następująco: „Fakt jest teoretycznie ukonstytuowanym twierdzeniem, podtrzymy-

\footnotetext{
11 Tamże, 25-27.

12 Tamże, 28.
} 
wanym przez teoretycznie zapośredniczone dowody i przedstawianym jako część teoretycznego ujęcia rzeczywistości. Fakt jest podważalnym następstwem teoretycznie ustanowionego porządku rzeczy". Wynika więc z tego, kontynuuje swoją krytykę profesor Gergen, iż z chwilą, gdy teoria zostaje przyjęta przez grupę, używa się jej do interpretowania zdarzeń w taki sposób, że ona sama wydaje się faktycznie prawdziwa. To co jest „obiektywnie” prawdziwe, zależy zatem nie od tego, czym jest dany przypadek, lecz od społeczności, w której uczestniczymy. A w świetle wzrastającej dostępności ,innych głosów” odkrywamy rosnący zakres „,innych prawd”"13 i zarazem pewnie coraz większą trudność odnalezienia prawdy o samym sobie, co się przejawia w coraz większym zagubieniu współczesnego człowieka i także w trudnościach w przebaczeniu i dalszym trwaniu w związkach, które dziś bardzo szybko ulegają rozpadowi.

Znamiennie kończy profesor Gergen rozdział o kryzysie prawdy i zarazem kryzysie człowieka i jego esencjalnym, istotowym Ja. Podkreśla, iż obecne zamieszanie $\mathrm{w}$ środowisku naukowym przygotowuje nas na zejście „Ja” ze sceny. Pojawienie się wielu głosów tworzy sytuację, w której roszczenia do obiektywnej prawdy nie mogą być już dłużej gwarantowane. Co więcej, ponieważ roszczenia do prawdy i dokładnego opisu przesłaniają interesy tych, którym służą, spokojny głos obiektywnego zapewnienia jest tym bardziej niebezpieczny. Dlatego rozpada się wiara w obiektywną wiedzę o indywidualnej osobie - o umyśle, emocjach, intencjach itp. Zagrożony staje się także obraz autonomicznego podmiotu wiedzy, prywatnie obserwującego i dzielącego swe myśli z innymi. Według obecnych, krytycznych ujęć rozpada się rozróżnienie między przedmiotem i podmiotem, umysłem i światem, pojawia się założenie, że słowa są zewnętrznymi znakami wewnętrznych znaczeń, przedmiot indywidualnych wypowiedzi jest dekonstruowany, a jednostka powoli rozpływa się w wielkim tańcu wspólnotowego życia ${ }^{14}$. W takim klimacie będzie coraz trudniej o konstruktywną dla człowieka komunikację interpersonalną i przebaczenie.

${ }^{13}$ Kenneth Gergen, Nasycone Ja. Dylematy tożsamości w życiu współczesnym, tłum. Mirosława Marody (Warszawa: Wydawnictwo Naukowe PWN, 2009), 126.

14 Tamże, 142. 


\section{Kryzys relacji milości jako podłoże trudności w komunikacji i przebaczeniu}

Przebaczenie bywa trudnym procesem, gdy mamy do czynienia z kryzysem prawdy, ale kryzysowi prawdy towarzyszy także bardzo bolesny dla człowieka kryzys miłości, który moim zdaniem jest głównie związany z redukcjonizmami w koncepcji człowieka i, konsekwentnie, koncepcji miłości. W tym miejscu pragnę odwołać się do koncepcji Victora Frankla, lekarza, psychiatry, a zarazem niezwykłego filozofa, który przeżył dramat bardzo trudny do przebaczenia, a konkretnie pobyt - jako więzień - w nazistowskim obozie koncentracyjnym w Dachau. Profesor Frankl podpowiada kilka istotnych dla naszych poszukiwań wskazań.

- człowiek nie może być rozpatrywany i traktowany w sposób abstrakcyjny, dziś także w sposób wirtualny, ponieważ jego istnienie rozgrywa się tu i teraz w świecie, w konkretnym miejscu i czasie; czasem mała miejscowość jest źródłem niezwykłego szczęścia, a potężne aglomeracje mogą prowadzać do zagubienia;

- człowiek nie może być również rozpatrywany i traktowany w sposób zredukowany, to znaczy sprowadzony do kategorii tylko biologicznych, fizyko-chemicznych lub społecznych, a dziś często do kategorii ekonomicznych; redukcjonizmy mogą dotykać szczególnie drastycznie właśnie sfery miłości, która redukowana albo tylko do sfery biologicznej, albo jakiegoś jednego wymiaru staje się doświadczeniem okaleczającym osobowość; redukcjonizmy bowiem - zdaniem profesora Frankla - prowadzą do nihilizmu, czyli do dramatycznego poczucia pustki egzystencjalnej, którą dziś coraz powszechniej zauważamy;

- człowiek, a szczególnie sfera miłości, pragnie pełni, czyli zintegrowanych w osobie trzech wymiarów: 1) somatycznego, 2) psychicznego, 3) duchowego, czyli noetycznego;

- istnienie sfery duchowej jest dla Viktora Frankla oczywiste tak samo jak istnienie sfery somatycznej i psychicznej; tutaj także mogą pojawiać się niebezpieczne dla pełnego, harmonijnego rozwoju człowieka i jego miłości, a także zdolności przebaczania, redukcjonizmy, które mogą dotykać zarówno sfery somatycznej, jak i psychicznej, ale także duchowej; każdy z tych redukcjonizmów jest niebezpieczny i ostatecznie destruktywny dla osobowości człowieka; drogą do 
pełnego integralnego rozwoju jest integralna koncepcja człowieka i miłości, co jest konieczną bazą do procesu przebaczania;

- źródłem dynamizmu człowieka i jego najważniejszą potrzebą jest dążenie do sensu, dążenie do znalezienia sensu życia, jest to potrzeba dominująca i zasada życia; zdaniem Viktora Frankla sens tkwi w samym życiu, życie ludzkie ma obiektywny sens, trzeba go tylko odkryć, odczytać i realizować; Frankl rozróżnia sens cząstkowy, który odkrywamy w naszych konkretnych działaniach, oraz sens całościowy (nadsens) świata i życia; zdaniem profesora Frankla tym, co gwarantuje totalną sensowność wszystkiego, jest odkrywany i przeżywany przez człowieka Bóg; zdanie to jest absolutnie fundamentalne dla życia, które poszukuje usensownienia; dziś deficyty sensu są szczególnym źródłem wielorakich trudności ludzkich, wzrasta liczba trudności psychicznych, od lęków, fobii, depresji, aż po tendencje suicydalne (samobójcze) ${ }^{15}$; z kolei swoisty „deficyt Boga" owocuje deficytami w wielu obszarach życia człowieka, konsekwencją mogą być także problemy z przebaczaniem, bo przecież pierwszym nieustannie nam wybaczającym jest Bóg, który uczy nas wybaczenia (,jeśli nie przebaczycie ludziom, i Ojciec wasz nie przebaczy wam waszych przewinień...”: Mt 6, 14-15);

- według Viktora Frankla człowiek jest istotą pociąganą przez wartości, a nie popychaną przez popędy; Frankl nie zaprzeczał istnieniu w człowieku popędów, ale w jego koncepcji człowiek jawi się jako istota bardziej pociągana przez wartości niż popychana przez popędy $i$ to jest potężna nadzieja na lepszy świat i lepszego człowieka, albowiem człowiek ma w sobie siłę pociągającą na wyższe poziomy i potrafi sublimować potrzeby, czyli przenosić na wyższe poziomy, potrafi także przebaczyć nawet w najtrudniejszych sytuacjach i wznosić się ponad słabości; dziś, gdy rywalizacja w wielu sektorach życia społecznego i ekonomicznego, także w edukacji, jawi się jako podstawowy mechanizm, rodzi się także powszechne wołanie o więcej wzajemnej ludzkiej życzliwości, współpracy, wsparcia, które to właśnie mechanizmy dają nadzieję na zrozumienie i przebaczenie w atmosferze dużego tempa życia i walki o zaspokojenie indywidualnych potrzeb;

15 Zob. Manfred Spitzer, Cyberchoroby. Jak cyfrowe życie rujnuje nasze zdrowie, thum. Małgorzata Guzowska (Słupsk: Dobra Literatura, 2016). 
- doświadczenie obozu nauczyło Viktora Frankla, że człowiek jest zdolny stawić czoło warunkom nawet najokrutniejszym, człowiek przeżyje każde ,jak”, jeśli ma wyraźnie „po co” - pozwoliłbym sobie dodać, że jeszcze jeśli ma „dla kogo”; człowiek bowiem zdolny jest z natury swojej do transcendencji, przekraczania determinant biologicznych i społecznych, człowiek potrafi przekraczać konieczności, bo jest z natury istotą transcendującą różne ograniczenia i wznoszącą się na szczyty ludzkich możliwości, nosi bowiem w sobie pierwiastek boski, dlatego zdolny jest do heroizmów, także w tak trudnej kwestii, jaką jest przebaczenie;

- Viktor Frankl mocno akcentuje wolność człowieka; człowiek bowiem jest także mocno uwarunkowany ograniczeniami ze świata przyrodniczego i społecznego i ze strony własnego organizmu, ale nie jest zdeterminowany przez te czynniki - może pozostać wewnętrznie wolny i to jest przestrzeń do zdolności przebaczenia, która to zdolność może być oczyszczająca ${ }^{16}$.

\section{W kierunku edukacji ku przebaczeniu}

Edukacja ku umiejętności przebaczenia związana jest z podążaniem przez profesjonalizację komunikacji w kierunku dojrzałej osobowości, która jest najlepszą drogą do lepszego społeczeństwa. Korzystając z typologii cech dojrzałej osobowości Gordona Allporta, chciałbym zaproponować kilka wskazówek dla wychowania w odniesieniu do przebaczenia. Przebaczenie warunkują, moim zdaniem, następujące cechy:

- adekwatna ocena rzeczywistości i siebie, widzenie siebie, ludzi i spraw we właściwych proporcjach, realistycznie, prawdziwie; adekwatna to znaczy niezawyżona i niezaniżona;

- jednocząca filozofia życia, zawierająca odpowiedzi na pytania dotyczące spraw najbardziej zasadniczych - kim jest człowiek, skąd się wziął, po co żyje, dokąd zmierza?; jednocząca filozofia życia scala te informacje, porządkuje, harmonizuje i daje świadomość celów i zadań życiowych, wyznacza perspektywę wzrastania;

16 Za: Władysław Szewczyk, Kim jest człowiek. Zarys antropologii filozoficznej (Tarnów: Wydawnictwo Diecezji Tarnowskiej, 2000), 71-73. 
- nastawienie przyszłościowe i celowe - zdolność do przejęcia odpowiedzialności za innych, przeciwieństwem jest tak zwana postawa prowizoryczna, czyli z dnia na dzień;

- zdolność do głębokiego emocjonalnego przywiązania do ludzi, serdeczna więź, zdolność do syntonii, czyli „współbrzmienia” oraz empatii, a więc „wczuwania się”, zdolność do przebaczenia oraz prospołeczność, to znaczy umiejętność bycia dla innych z równoczesną zdolnością rezygnowania z siebie;

- równowaga emocjonalna - brak nadmiernej reakcji na bodźce wynikające z popędów (tzw. równowaga pionowa) oraz równowaga pozioma, czyli zdolność nawiązywania satysfakcjonujących i poprawnych relacji z ludźmi; także zdolność panowania nad emocjami w sytuacjach trudnych, stresowych;

- poczucie sensu życia, a więc uznanie sensowności istnienia, pracy i rozrywki, cierpienia i bólu, poszukiwanie głębi życia ${ }^{17}$.

\section{Podsumowanie}

Jan Paweł II w encyklice o Bożym miłosierdziu (Dives in misericordia) ukazuje szczególny przykład wielkoduszności w przebaczeniu, jakim jest przebaczający swojemu marnotrawnemu synowi ojciec. Papież znamiennie stwierdza, iż ta przypowieść uświadamia nam, że relacja miłosierdzia opiera się na wspólnym przeżyciu dobra, jakim jest człowiek, na wspólnym doświadczeniu tej godności, jaka jest jemu właściwa. Dalej podkreśla Jan Paweł, iż w swoim właściwym i pełnym kształcie miłosierdzie objawia się jako dowartościowanie, jako podnoszenie w górę, jako wydobywanie dobra spod wszelkich nawarstwień zła, które jest w świecie i w człowieku ${ }^{18}$. Edukacja ku przebaczeniu jest esencjalnie oparta o troskę o człowieka jako osobę i jego godność, a nieodłącznie związana jest z procesem profesjonalizacji komunikacji interpersonalnej, jako sposobem podnoszenia siebie nawzajem w górę i wydobywania z siebie tego co najlepsze. Dynamikę temu całemu procesowi nadaje na pewno chrześcijaństwo, jako system społeczno-religijny w najlepszy sposób dowartościowujący człowieka i pomagający mu ciągle się odnajdywać na nowo, nawet wtedy, gdy jest „synem marnotrawnym”.

17 Za: Władysław Szewczyk, Rozumieć siebie i innych. Zarys psychologii (Tarnów: Biblos, 1998), 127-128.

18 Jan Paweł II, Dives in Misericordia, nr 6 (Watykan: 1980). 
To jest zapewne nasza największa nadzieja, która zawieźć nie może, którą szczególnie swoją osobą ukazuje, promieniuje i realizuje aktualnie papież Franciszek, człowiek gorącą, skromną i pokorną miłością kochający Boga i człowieka.

\section{Interpersonal Communication and Forgiveness Process (Summary)}

In the light of human and social sciences, forgiveness might be defined as one of the most difficult processes. This is connected with interpersonal communication; thus, its formation, development as well as difficulties as hurts, hypocrisy or even destruction of other human being. Simultaneously, Christianity expresses the belief that a human being - despite his weaknesses - is a good being by nature, capable of changing and pursuing the good, truth, beauty and love as well as forgiveness. This article discusses the issue of forgiveness in relation to interpersonal communication, by analysing relationships between these processes, difficulties with forgiveness resulting from communication problems, as well as difficulties with forgiveness related to the specific character of the contemporary conditions of communication processes - the crisis of the truth and love.

Key words: interpersonal communication; forgiveness; personalism; the crisis of truth; the crisis of love.

\section{Komunikacja interpersonalna a proces przebaczania (Streszczenie)}

Przebaczenie w świetle nauk o człowieku i społeczeństwie można określić jako jeden z najtrudniejszych procesów. Jest on związany bowiem z komunikacją interpersonalną, a więc $\mathrm{z}$ jej powstawaniem, rozwojem, a także trudnościami, takimi jak: zranienia, zakłamania, a nawet niszczenie drugiego człowieka. Równocześnie chrześcijaństwo wyraża przekonanie, że człowiek - mimo słabości - jest z natury istotą dobrą, zdolną do przemiany i do podążania w stronę dobra, prawdy, piękna i miłości, a także do okazywania przebaczenia. W niniejszym artykule podjęto zagadnienie przebaczenia w odniesieniu do komunikacji interpersonalnej, analizując kolejno zależności między tymi procesami, trudności z przebaczaniem wynikające z problemów z komunikacją, oraz trudności z przebaczaniem powiązane ze specy- 
fiką współczesnych uwarunkowań procesów komunikacyjnych - kryzysem prawdy oraz miłości.

Słowa kluczowe: komunikacja interpersonalna; przebaczenie; personalizm; kryzys prawdy; kryzys miłości.

\section{Bibliografia}

Bartnik, Czesław S. Personalizm. Lublin: KUL, 2000.

Dziewiecki, Marek. Psychologia porozumiewania się. Kielce: Jedność, 2000.

Gergen, Kenneth. Nasycone Ja. Dylematy tożsamości w życiu wspótczesnym, thum.

Mirosława Marody. Warszawa: Wydawnictwo Naukowe PWN, 2009.

Goleman, Daniel. Focus. Sztuka koncentracji jako ukryte dążenie do doskonatości. Poznań: Media Rodzina, 2014.

Jan Paweł II. Encyklika Dives in misericordia. Watykan: 1980.

Morreale, Sherwyn P., Brian H. Spitzberg, J. Kevin Barge. Komunikacja między ludźmi, tłum. Dorota Kobylińska, Paweł Izdebski, Aleksandra Jaworska-Surma. Warszawa: Wydawnictwo Naukowe PWN, 2008.

Spitzer, Manfred. Cyberchoroby. Jak cyfrowe życie rujnuje nasze zdrowie, thum. Małgorzata Guzowska. Słupsk: Dobra Literatura, 2016.

Szewczyk, Władysław. Rozumieć siebie i innych. Zarys psychologii. Tarnów: Biblos, 1998.

Szewczyk, Władysław. Kim jest człowiek. Zarys antropologii filozoficznej. Tarnów: Wydawnictwo Diecezji Tarnowskiej, 2000.

Szmyd, Jan. Zagrożone człowieczeństwo. Regresja antropologiczna w świecie ponowoczesnym. Katowice: Śląsk Wydawnictwo Naukowe, 2015. 